\title{
RELATIONAL CAPITAL IN THE CONTEXT OF INTERNATIONALIZATION
}

\section{JOANNA ŻUKOWSKA, ${ }^{1}$ HIERONIM JĘDRZEJEWSKI ${ }^{2}$}

\begin{tabular}{l|l} 
& $\begin{array}{l}\text { Warsaw School of Economics } \\
1 \text { e-mail: joanna.zukowska@sgh.waw.pl } \\
\text { 'e-mail: hieronim@hotmail.com }\end{array}$ \\
$\begin{array}{l}\text { RECEIVED } \\
\text { ACCEPTED }\end{array}$ & $\begin{array}{l}13 \text { February } 2017 \\
28 \text { May } 2017\end{array}$ \\
CLE & $\begin{array}{l}\text { A13, O33, R30, P13, J24 } \\
\text { KEYWICATION }\end{array}$ \\
ABSTRACT & $\begin{array}{l}\text { Relational capital, internationalization, distance, enterprise, human capital } \\
\text { appreciated more and more frequently due to its positive impact on enterprises, with particular attention paid } \\
\text { to internationalization. The purpose of this paper is to present the issues of relational capital in the context } \\
\text { of internationalization. The paper will emphasize the issue of relational capital and internationalization. } \\
\text { Furthermore, the question of distance as a term in building enterprise's relational capital as well as its } \\
\text { stakeholders will be considered herein. The statistics of internationalization publication will also be presented. }\end{array}$
\end{tabular}

\section{Introduction}

Relational capital is a topic which has drawn growing interest throughout the recent years (McKeever, Anderson, 2014; Czuba, Szczepaniec, Jurkiewicz, 2012; Walecka, 2016; Miocevic, 2016). Its value is appreciated more and more frequently due to its positive impact on enterprises, with particular attention paid to internationalization (Hitt et al., 2006). 
The purpose of this paper is to present the issues of relational capital in the context of internationalization. The question of relational capital has been defined by numerous researchers (Przybylska, 2015; García-Merino et al., 2014; Welbourne, Pardo-del-val, 2009; Barao, Rodrigues da Silva, 2012). However, the diversity of approaches to the definition has made the authors select one definition, in their opinion, corresponding to the subject matter of the studies they conduct in the best way. Upon analysis of the available studies, the authors have decided to recommend for the further studies the relational capital definition treating it as a dynamically varying, both in terms of quantity and quality, network of enterprise connections within its business environment. The connections within such network may be characterized with various intensity and quality. However, it is well-known that a good relationship is most of all based on trust and cooperation. Thus, relational capital is a significant element that creates the unique value of enterprise, which affects its competitive advantage. Moreover, it gives the enterprise an opportunity for success in the internationalization process (Wasowska, 2009). The authors acknowledge that such definition is wide and enables them to grasp and simultaneously study relational capital in three major fields - the impact on efficiency and competitiveness of enterprises, the impact on development of innovativeness, and the participation in the internationalization process.

Due to the fact that this paper is an introduction to planned years of study on relational capital, we should emphasize that this study will be of an introductory and guiding nature. Moreover, emphasis should be put on the fact that the study would cover the third pillar of interest, namely the role of relational capital in the internationalization process.

\section{Internationalization - publication statistics}

Considering the purpose of this study, internationalization seen as one of the determinants affecting the relational capital becomes a very important element, particularly in the long-run (Gorynia, Jankowska, 2007).

At first the authors analyzed the frequency of publications devoted to internationalization itself and internationalization in the context of relational capital through the years 2006-2016. The Proquest, Emerald and Ebsco bases were analyzed.

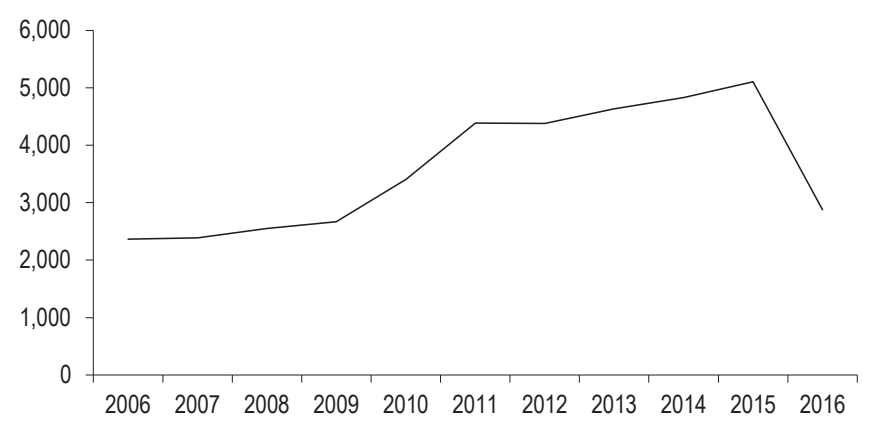

Figure 1. The analysis of the number of publications of the keyword "internationalization"

in the Proquest base through 2006-2016

Source: the authors' own study. 


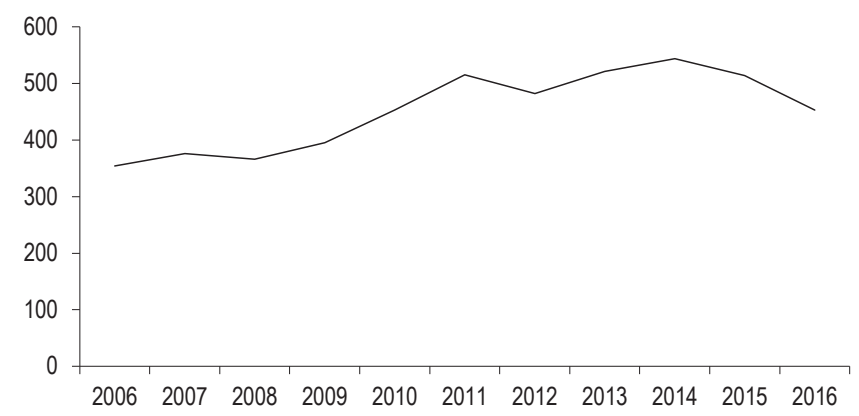

Figure 2. The analysis of the number of publications of the keyword "internationalization" in the Emerald base through 2006-2016

Source: the authors' own study.

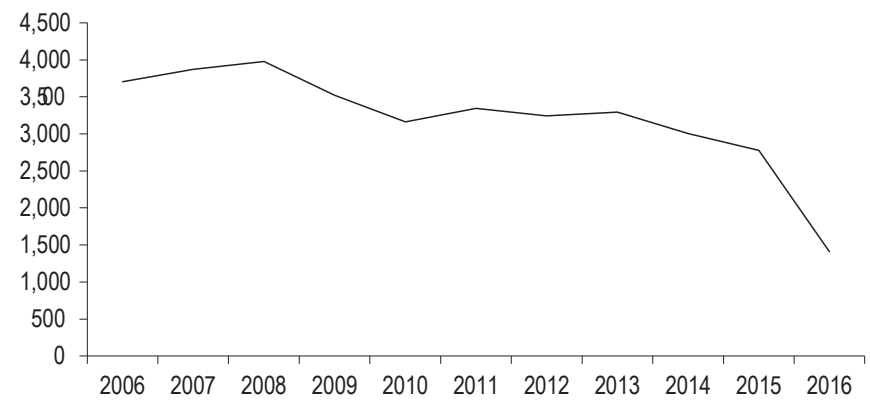

Figure 3. The analysis of the number of publications of the keyword "internationalization" in the Ebsco base through 2006-2016

Source: the authors' own study.

The data analysis indicated that the very term of internationalization very often occurred in the publications. However, the data concerning the keyword and presented in the databases are divergent. The Proquest base shows a significant growth of interest in the term, in the Emerald base a slight growth has been noticed, while the Ebsco base indicated a drop of interest. It should be emphasized that the number of publications within each of the three bases is approximate. The fact that internationalization in terms of human capital practically does not exist deserves particular attention. The correlation of internationalization with relational capital is scarce being expressed in less than 10 papers within each base. Accordingly, the diagrams presented herein concern the term of internationalization only. This is another signal that a substantial research gap occurs in this field and it needs to be filled. 


\section{Relational capital versus internationalization}

A significant characteristic of the processes is the dynamics of development based on the mutual effects throughout their course. The processes coexist and affect each other naturally, as a result the value of relational capital correlated with the internationalization process represents the derivative of this process performance effectiveness.

The international expansion strategies built on the foundations of international trade theories represent an instrument of strategic planning and implementation of the assumed plans in order to gain new sales markets for the goods and services offered. The planning and structuring of international expansion strategies require the simultaneous preparation of the relational background, which will constitute a basis for realization of the said strategies. Relational capital as part of intellectual capital represents a unique, unrepeatable quality, characteristic for a particular entity only and it is a significant factor in building the competitive advantage. Perechuda, ChomiakOrsa (2013) point out the growing phenomenon of increasing difference between the enterprises and the value resulting from their accounts. After Barney (2001), they emphasize the durable competitive advantage resulting from impossibility to imitate and replace the organization's resources - as the relationship dynamics cannot be copied and used in the expansion process of another entity.

Distance is a significant term in the presentation of relational capital impact on the internationalization process. The term determines the distance occurring between the entity and the target market, it defines the method of reduction or elimination of distance. An important factor in relationship definition is also the type of stakeholders whose subjectivity conditions the type of such relationships (Berry et al., 2010).

\section{Distance as a notion in building the enterprise's relational capital}

In the process of internationalization, the build-up of relational capital takes place in the conditions of distance not only understood as geographical distance, but also as distance resulting from economic, structural, legal, political, institutional as well as cultural and mental conditions. The multidimensional nature of the term of distance is most of all proven by the necessity to assume a perspective the particular category should be described from. Ghemawat (2001) formulated one of the first typologies of distance. The first of the authors formulated the CAGE model (cultural, administrative, geographic, economic), which was later extended by Berry et al. (2010) by the demographic, financial, knowledge-related, political and communicational dimensions.

The meaning of geographical distance between an enterprise and the target market is significant in terms of discussion on the impact of advanced communication technologies and state-of-the-art transportation forms on international exchange. The technologies enable instantaneous exchange of information between business partners disregarding the distance as well as technical exchange of goods and services within the shortest time possible. Thanks to technology the geographical distance has been dramatically reduced and the speed of resource flow has become a significant element of building competitiveness of enterprises on the global market. The factors characterizing the institutional distance were formulated by Scott, who pointed out the correlation between the institutional impact on the enterprises in the field including cognitive structures, characteristic for a particular community, normative field related to the values and standards of social behaviors and regulatory, concerning legal regulations applicable on a particular market (Scott, 1995). The economic distance is most of all related to the difference of economic development level between the particular areas. 
The studies on literature devoted to the category of distance (Wassowska, Ciszewska-Mlinaric, 2012) point out the high interest in the cultural distance, which, in spite of great popularity among researchers, does not lead "to expansion of knowledge about cultural distance significance". They indicate the ambiguity of impact of the cultural distance on increasing the pressure on the local adaptation (Bartlett, Ghoshal, 1989). Although the category of mental distance appeared as early as in the 1950s, in the internationalization theory it appeared in the Uppsala internationalization model in the 1970s only. The fundamental characteristic of the model is the gradual, sequential or evolutionary involvement of enterprise into a particular expansion market. The authors of the concept (Johanson, Wiedersheim-Paul, 1975; Johanson, Vahlne, 1977) stated that the mental distance, in addition to the lack of necessary resources, including knowledge about a particular market and the risk related to expansion, means restrictions or rather conditions of launching a particular market, whereby the mental distance appearing between the domestic and the target market is correlated with geographical distance. Gorynia, Jankowska (2007) also points out the phenomenon of skipping through the subsequent internationalization stages (leapfrogging), characteristic for large enterprises. He notices that they tend to "launch mentally distant markets at more and more early expansion phases". Wąsowska and Ciszewska-Mlinaric (2012) rightly emphasize the significance of distinguishing cultural distance from mental one, the latter describing "differences between countries perceived by managers" and that "mental distance should not be put into operation by objective indexes". In terms of internationalization direction, the cultural distance does not represent a significant market selection factor, whereas in case of early internationalization of enterprise, the market selection is related to the low level of mental distance. Cultural and mental conditions constitute the basis for exchange on the relational level and for building enterprise's relational capital as a process.

\section{Building relational capital and its stakeholders}

The technical possibilities of communication under geographical distance conditions represent just a means for building relationships. Their building starts when the business partners tend to make contact in order to conclude a transaction and achieve the intended benefits. The space for building cultural and mental relationships is created. According to the operational approach to the enterprise business, the first successful transaction elevates the level of the parties' trust and creates space for building relationships between them based on the knowledge and experience gained in such a way. If the willingness to build relationships between business partners are to be acknowledged in the initial phase of building relational capital, then, the next transaction approximates their relationships to repeating it and improves their quality. The process of building relationships with the target market, most frequently preceded by acquisition of knowledge on such market based on the available resources of knowledge located most of all within the sector the enterprise operates in, the general business space, virtual space as well as networks and social media. Significant sources of knowledge are in business environment institutions. From macroeconomic point of view, all the entities specified represent a mutually correlated, directly and indirectly, network of stakeholders who enter their mutual relationships. The direct correlations between stakeholders include most of all those aimed at direct transaction. Indirect relationships are those in which the relationships mean information exchange and knowledge acquisition. According to Costa et al. (2016) - the authors of a study related to management of information, knowledge and cooperation in internationalization, the relational capital is one of the three factors for deciding on enterprise internationalization. The other factors are the enterprise orientation and level of foreign language knowledge among the decision makers. 
A significant factor generating the internal relationships comprises the enterprise staff. Each enterprise employee has their own relational capital built prior to joining an organization and being built on an ongoing basis within the activity for the organization they work for at present. The total of relational capitals of the enterprise employees and the relational capital of the organization represent a set of relationship values, which may be called the enterprise's relational capital. Creating a relational capital of an enterprise is effected in interpersonal relationships and also in the relationships of enterprise as an organization with the environment. In the first case it is of a dynamic nature and occurs within the knowledge exchange process inside the enterprise and between the employees of the enterprise and employees of an external organization, for example a business partner. Thus, a network of correlations is created and it represents a structure which value depends on quality, i.e. the strength of the correlations. The more flexible and expandable, attractive and able to enter into relationships are the individuals in the network, the stronger their correlations will be.

The mechanism of creating the relational capital in the internationalization process is similar to the conditions under which the enterprise builds the capital in its close environment, on the local market. The growing distance increases the deficiency of knowledge concerning the area to be launched. The enterprise in the process of overseas expansion struggles for gaining the necessary knowledge on the market of target expansion and is subject to pressure of adaptation to the conditions governing the specific area.

Building relational capital in the internationalization process demands special focus put on creating appropriate conditions for implementation of expansion and development plans on a particular market. The process of enterprise adaptation on all the levels enabling legal-administrative and structural functioning on a market simultaneously requires adaptation to the cultural conditions and multi-level reduction of distance. Such distance concerning good relationships with local business partners enables access to the knowledge and information on the specific nature of such market. Costa et al. (2016) point out the factors related to the role of relational capital in building motivation mechanisms at the stage of initiating the process. They also mention such factors as: building mutual trust affecting the length of relationships, respect to cultural differences, patience, ability to enter close interpersonal relationships, acquiring friends and other. Cultural similarities reduce the distance and support the processes of building trust as a key factor in building the relational capital. It seems that the relational capital resources held by the enterprise's staff are more significant in building the internationalization process at the initial stage of the expansion, however its value is subject to impartial measurement only as the total of the organization's relational capital.

\section{Conclusions}

The number of studies on the issues of relational capital as a significant element of building competitive advantages grows along with the awareness of necessity to build the enterprise value based on the intellectual capital, understanding the meaning of relationships, building the aforementioned values through structured networks and development of the mechanisms forming them. Creating the relational capital in the internationalization process may positively impact the relationships between enterprises and environment in the distant areas from the enterprise's location and, simultaneously, it may reduce the risk of carrying out business under culturally alien conditions. The studies on distance as a multi-level phenomenon enable us to track the relationships of enterprises with the environment in the context of structural internal and external conditions. A closer look at the issues of correlations of relational capital in the internationalization process, most of all, due to the uniqueness of each such process, conditions related to the target market and dynamics of the mutual effects appearing during the structuring 
of such processes also seem to be an interesting issue. The research gap identified by the authors will be subjected to further studies.

\section{References}

Barão, A. \& Rodrigues da Silva, A. (2012). Handbook of Research on Enterprise 2.0: Technological, Social, and Organizational Dimensions: IGI Global.

Barney, J.B. (2001). Is the resource-based "view" a useful perspective for strategic management research? Yes. Academy of Management Review, 26 (1), 41-56.

Bartlett, C.A. \& Ghoshal, S. (1989). Managing Across Borders: The Transnational Solution. Boston: Harvard Business School Press.

Berry, H., Guillén, M.F. \& Zhou, N. (2010). An institutional approach to cross-national distance. Journal of International Business Studies, 41 (9), 1460-1680.

Costa, E., Soares, A.L. \& Sousa, J.P. (2016). Information, knowledge and collaboration management in the internationalization of SMEs: A systematic literature review. International Journal of Information Management, 36, 557-569.

Czuba, T., Szczepaniec, M. \& Jurkiewicz, T. (2012). Kapitał relacyjny a wyniki ekonomiczne małych i średnich firm w Polsce. Wyzwania gospodarki globalnej. Prace i Materiały Instytutu Handlu Zagranicznego Uniwersytetu Gdańskiego, 31 (2), 194-212.

García-Merino, J.D., García-Zambrano, L. \& Rodriguez-Castellanos, A. (2014). Impact of Relational Capital on Business Value. Journal of Information \& Knowledge Management, 13 (1), 1-8.

Ghemawat, P. (2001). Distance still matters: The hard reality of global expansion. Harvard Business Review, 79 (8), 137-147.

Gorynia, M. \& Jankowska, B. (2007). Teorie internacjonalizacji. Gospodarka Narodowa, 10, 21-44.

Hitt, M., Bierman, L., Uhlenbruck, K. \& Shimizu, K. (2006). The Importance of Resources in the Internationalization of Professional Service Firms: The Good, the Bad and the Ugly. The Academy of Management Journal, 49 (6), 1137-1157.

Johanson, J. \& Wiedersheim-Paul, F. (1975). The Internationalization of the Firm: Four Swedish Cases. Journal of Management Studies, $12(3), 305-323$.

Johanson, J. \& Vahlne, J.E. (1977). The Internationalization Process of the Firm: a Model of Knowledge Development and Increasing Foreign Market Commitments. Journal of International Business Studies, 8 (1), 23-32.

McKeever, E. \& Anderson, A.J. (2014). Entrepreneurship and mutuality: social capital in processes and practices. Entrepreneurship \& Regional Development, 26 (5), 453-477.

Miocevic, D. (2016). The antecedents of relational capital in key exporter-importer relationships. An institutional perspective. International Marketing Review, 33 (2), 196-218.

Perechuda, K. \& Chomiak-Orsa, I. (2013). Znaczenie kapitału relacyjnego we współczesnych koncepcjach zarządzania. Biblioteka Nauki, Zarządzanie i Finanse, 4 (2).

Przybylska, N. (2015). Rozwój kapitału relacyjnego poprzez wykorzystanie platform internetowych Web 2.0. Współczesne Problemy Ekonomiczne, 11, 217-226.

Scott, W.R. (1995). Institutions and Organizations: Theory and Research. Thousand Oaks.

Walecka, A. (2016). Kapitał relacyjny przedsiębiorstw w kryzysie. Prace Naukowe Wydawnictwo Uniwersytetu Ekonomicznego we Wrocławiu, 422, 158-172.

Walecka, A. (2016). Kapitał relacyjny przedsiębiorstw w kryzysie (Enterprises relational capital in crisis). Prace Naukowe Wydawnictwo Uniwersytetu Ekonomicznego we Wrocławiu, 422.

Wąsowska, A. \& Ciszewska-Mlinaric, M. (2009). Znaczenie dystansu w procesie internacjonalizacji przedsiębiorstw. Management and Business Administration. Central Europe, 6 (119), 3-22.

Wąsowska, W. (2009). Umiędzynarodowienie firm z krajów rozwijających się - rola sieci społecznych. In: M. Cisek (ed.), Kapitał relacyjny w nowoczesnej gospodarce. Warszawa: EMKA.

Welbourne, T.M. \& Pardo-del-VAL, M. (2009). Relational Capital: Strategic Advantage for Small and Medium-Size Enterprises (SMEs) Through Negotiation and Collaboration. Group Decision and Negotiation, 18 (5), 483-497.

Cite this article aS: Żukowska, J., Jędrzejewski. H. (2017). Relational Capital in the Context of Internationalization. European Journal of Service Management, 22 (2), 61-67. DOI: 10.18276/ejsm.2017.22-08. 